\title{
Experimental infection of Atlantic salmon Salmo salar pre-smolts by i.p. injection with new Irish and Norwegian salmonid alphavirus (SAV) isolates: a comparative study
}

\author{
K. E. Christie ${ }^{1}$, D. A. Graham ${ }^{2, *}$, M. F. McLoughlin ${ }^{3}$, S. Villoing ${ }^{1}$, \\ D. Todd ${ }^{2}$, D. Knappskog ${ }^{1}$ \\ ${ }^{1}$ Intervet Norbio, Thormohlensgt. 55, 5008, Bergen, Norway \\ ${ }^{2}$ Veterinary Sciences Division, Stoney Road, Stormont, Belfast BT4 3SD, UK \\ ${ }^{3}$ Aquatic Veterinary Services, 35 Cherryvalley Park, Belfast BT5 6PN, UK
}

\begin{abstract}
Atlantic salmon Salmo salar L. pre-smolts were experimentally infected with 2 different isolates of salmonid alphavirus (SAV): a Subtype 1 isolate from Ireland and a Subtype 3 isolate from Norway. Sequential samples of tissue and blood were collected during a period of 20 wk post injection and subjected to virus isolation from kidney tissue and serum, detection of viral nucleic acid in heart tissue and serum by real-time RT-PCR, detection of specific antibodies by virus neutralisation assay, and histopathological examination. Successful reproduction of pancreas disease (PD) was obtained by intraperitoneal (i.p.) injection of both isolates. No mortality was observed post infection in either group, but typical PD histopathological lesions in heart and pancreas tissue were observed with both isolates. The prevalence and severity of lesions in the pancreas, heart, skeletal muscle and brain were similar in both groups with only subtle differences recorded. Re-isolation of virus from kidney tissue was performed at 7 and 14 d post infection (d p.i.) only and was positive for both test groups at both sampling points. Isolation of virus from sera from both groups was positive at 4 to $14 \mathrm{~d}$ p.i., but was negative at later sampling points when antibody production had begun. Virus may be detected only during the acute phase using both methods. Specific neutralising antibodies could be detected for both test groups from Day 21 p.i. until the end of the experiment at $140 \mathrm{~d}$ p.i. Peak antibody titres were seen $70 \mathrm{~d}$ p.i. Using real-time RT-PCR, pancreas disease virus (PDV)-specific RNA was detected frequently in serum samples up to $14 \mathrm{~d}$ p.i. and occasionally thereafter. In contrast, viral RNA could still be detected in the heart tissue of fish from both groups for at least $140 \mathrm{~d}$ p.i.
\end{abstract}

KEY WORDS: Salmonid alphavirus · Pancreas disease - Experimental infection · RT-PCR · Serology Virology $\cdot$ Subtype $1 \cdot$ Subtype 3

Resale or republication not permitted without written consent of the publisher

\section{INTRODUCTION}

Experimental infection of Atlantic salmon Salmo salar L. smolts or pre-smolts with the original Irish reference isolate of pancreas disease virus (PDV) (F93125) was reported by McLoughlin et al. (1996), where lesions typical of naturally occurring PD were observed. In recent years it was observed that this isolate was apparently less pathogenic in experimental infections, producing very mild infections with minimal histopathological changes in the fish (K. E. Christie pers. obs.). During the last few years, new PDV isolates from Ireland and Norway (Graham et al. 2003, Jewhurst et al. 2004, Hodneland et al. 2005) have been shown to induce more severe histopathological lesions in Atlantic salmon than the reference isolate (K. E. Christie pers. obs.). Recent nucleotide sequencing studies indicated that salmonid alphaviruses (SAV) can be assigned to 3 genetically different subtypes (Hodneland et al. 2005, Weston et al. 2005). Using the des- 
ignation of Weston et al. (2005), the original salmon pancreas disease virus (SPDV) reference strain and similar viruses are Subtype $1 \mathrm{SAV}$, isolates from sleeping disease (SD) are Subtype 2, and the recently identified Norwegian isolates are Subtype 3. While experimental work contrasting the outcomes of infection with Subtype 1 and 2 isolates have previously been published (Boucher \& Baudin-Laurencin 1996, Weston et al. 2002), no comparative studies of Subtype 1 and 3 viruses have yet been described. The current study was therefore initiated to provide comparative data on the clinical, histopathological, virological and serological changes produced by representative viruses under experimental conditions. A secondary goal was to generate samples and data on the comparative performance of a range of diagnostic tests and information on the epidemiology of SAV infection.

\section{MATERIALS AND METHODS}

Preparation of inocula. Two SAV isolates were cultured in chinook salmon embryo 214 (CHSE-214) cells using standard techniques. Isolate F02-143 was made from an outbreak of PD in Ireland in 2002, and is a Subtype 1 SAV according to the classification of Weston et al. (2005). Isolate PD03-08 was from an outbreak of PD in Norway in 2003 and is classified as a Subtype 3 SAV. F02-143 and PD03-08 were grown at 4 th and 10th passage respectively, and yielded pools with titres of $10^{5.8} \mathrm{TCID}_{50} \mathrm{ml}^{-1}$ and $10^{5.5} \mathrm{TCID}_{50} \mathrm{ml}^{-1}$

Experimental fish. Five hundred mixed-sex Atlantic salmon Salmo salar parr weighing $40 \pm 5$ g were randomly assigned to 3 separate $1 \mathrm{~m}^{3}$ tanks in lots of 200 $(n=2)$ and $100(n=1)$. The population was screened for infectious pancreatic necrosis virus (IPNV) by virus isolation and for SAV and infectious salmon anaemia virus (ISAV) by real-time RT-PCR with negative results. Fish were maintained throughout in freshwater with a flow rate of $0.8 \mathrm{l}$ per $\mathrm{kg}$ fish per minute under the following conditions: temperature, 10 to $12^{\circ} \mathrm{C}_{i} \mathrm{pH}, 6.6$ to 6.9 ; and oxygen, 10.5 to $11.5 \mathrm{mg} \mathrm{l}^{-1}$. Maximum fish density was $20 \mathrm{~kg} \mathrm{~m}^{-3}$. Fish were acclimatised for $1 \mathrm{wk}$ before the experiment was initiated and monitored throughout for evidence of disease. Fish were fed to appetite throughout, with the exception of 12 to $24 \mathrm{~h}$ of food withdrawal before handling.

Experimental design and sampling. One set of 200 fish (Group 1) was anaesthetized and inoculated by intraperitoneal (i.p.) injection with isolate F02-143. The second set of 200 fish (Group 2) was similarly inoculated with isolate PD03-08. Both groups received a standardized dose of $2 \times 10^{3} \mathrm{TCID}_{50}$. The remaining 100 fish (Group 3) received a similar volume of an inoculum of CHSE-214 cells harvested and diluted to a ratio of 1:30 in Eagle's minimum essential medium (EMEM).

The groups were sampled at 4, 7, 14, 21, 35, 70, 105 and $140 \mathrm{~d}$ post infection (d p.i.). Tissue samples for histopathology and virus re-isolation and serum for virus and antibody detection were typically collected from 10 fish of each of the infected test groups. Samples of heart tissue and serum for PCR testing were taken from a parallel group of 10 fish. From the control group, samples of 2 parallel groups of 5 fish were taken at each sampling point. At 7, 14, 21, 35, 70 and $105 \mathrm{~d}$ p.i. the weights of 10 or 20 individual fish from each group were recorded and mean weights calculated.

Samples of heart, pancreas, kidney, skeletal muscle and brain tissue, collected into neutral buffered formalin for subsequent histopathological examination, were recovered from all groups at each time point.

Serum for antibody testing, virus isolation and RT-PCR was collected from all 3 groups on all occasions except 4 and 7 d p.i. (Group 2) and $140 \mathrm{~d}$ p.i. (Groups 1 and 2). Kidney tissue for virus isolation was collected from all 3 groups at 7 and $14 \mathrm{~d}$ p.i. only. Blood samples were stored overnight at $+4^{\circ} \mathrm{C}$ and centrifuged at $3000 \times g$ for $10 \mathrm{~min}$ and sera removed. Samples of kidney tissue and sera for virus isolation were stored in liquid nitrogen.

Heart samples for RT-PCR were collected from Groups 1 and 3 at all sample points, but from Group 2 on a single occasion only (140 d p.i., $n=30$ ). Samples of heart tissue for RT-PCR were submerged in $400 \mu \mathrm{l}$ RNAlater $^{\circledR}$ (Ambion), kept at $4^{\circ} \mathrm{C}$ overnight and stored at $-80^{\circ} \mathrm{C}$.

Histopathology. Tissue sections were examined as a blind study and the presence or absence of lesions recorded. Where lesions were observed (except kidney), the scoring system provided in Table 1 was used to semiquantify the distribution and severity of the tissue lesions. Both the number of fish with lesions in each tissue and the mean lesion score was calculated for each sampling event.

Virus isolation from kidney tissue. A sample of approximately $0.1 \mathrm{~g}$ kidney tissue was diluted to a ratio of 1:10 in EMEM, homogenised and centrifuged for $10 \mathrm{~min}$ at $5000 \times g$. A final 1:100 dilution of the supernatant in EMEM containing $2 \% \mathrm{v} / \mathrm{v}$ foetal calf serum (FCS), glutamine $(2 \mathrm{mM})$, heparin $(10 \mathrm{mM})$, non-essential amino acids $1 \% \mathrm{v} / \mathrm{v}$, gentamycin $\left(100 \mu \mathrm{g} \mathrm{ml}^{-1}\right)$ and amphotericin $\left(1.25 \mu \mathrm{g} \mathrm{ml}^{-1}\right)$ was inoculated in $25 \mathrm{~cm}^{2}$ CHSE-214 cell culture. After incubation for $7 \mathrm{~d}$ at $15^{\circ} \mathrm{C}$, infected cell culture medium diluted to final ratios of $1: 10$ and 1:100 with EMEM containing $2 \%$ FCS were inoculated onto a 48-well plate with fresh cell cultures. The first-passage infected cell cultures were examined for cytopathic effect (CPE) by microscopy. The second-passage infected cell cultures were examined by indirect immunofluorescent antibody test (IFAT) using SAV-specific monoclonal antibody (see below). 
Table 1. Salmo salar. Scoring of lesions in pancreas, heart and red and white skeletal muscle

\begin{tabular}{|c|c|}
\hline Score & Description \\
\hline \multicolumn{2}{|c|}{ Pancreatic lesions } \\
\hline 0 & Normal appearance \\
\hline 1 & Focal pancreatic acinar cell necrosis \\
\hline 2 & $\begin{array}{l}\text { Significant multifocal necrosis/atrophy of } \\
\text { pancreatic acinar tissue, plus some remnants } \\
\text { remaining }\end{array}$ \\
\hline 3 & Total absence of pancreatic acinar tissue \\
\hline $\mathrm{R}$ & Recovery of pancreas \\
\hline \multicolumn{2}{|c|}{ Heart lesions } \\
\hline 0 & Normal appearance \\
\hline 1 & $\begin{array}{l}\text { Focal myocardial degeneration } \\
\pm \text { inflammation }(<50 \text { fibres affected })\end{array}$ \\
\hline 2 & $\begin{array}{l}\text { Multifocal myocardial degeneration } \\
\pm \text { inflammation (50-100 fibres affected) }\end{array}$ \\
\hline 3 & $\begin{array}{l}\text { Severe diffuse myocardial degeneration } \\
\pm \text { inflammation }(>100 \text { fibres affected) }\end{array}$ \\
\hline $\mathrm{R}$ & Repair \\
\hline \multicolumn{2}{|c|}{ Red and white skeletal muscle lesions } \\
\hline 0 & Normal appearance \\
\hline 1 & Focal myocytic degeneration \pm inflammation \\
\hline 2 & $\begin{array}{l}\text { Multifocal myocytic degeneration } \\
\pm \text { inflammation }\end{array}$ \\
\hline 3 & $\begin{array}{l}\text { Severe diffuse myocytic degeneration } \\
\pm \text { inflammation }\end{array}$ \\
\hline $\mathrm{R}$ & Repair \\
\hline
\end{tabular}

Immunofluorescent antibody test (IFAT). The cell culture medium in 48- or 96-well plates was removed and 200 or $100 \mu \mathrm{l}$ of a $50 \% \mathrm{v} / \mathrm{v}$ ethanol/acetone mix (as appropriate) was added. Plates were incubated at $-20^{\circ} \mathrm{C}$ for $30 \mathrm{~min}$ and the wells washed 3 times with phosphate-buffered saline (PBS) containing 0.05\% Tween 20 (PBS-Tween). As appropriate, a volume of 200 or $100 \mu \mathrm{l}$ anti-SAV antibody (4H1 or 7A2) diluted 1:2000 in PBS (Welsh et al. 2000) was added to each well. Plates were then incubated for $1 \mathrm{~h}$ at room temperature and washed 3 times with PBS-Tween before addition of 200 or $100 \mu$ FITC conjugated anti-mouse diluted to a ratio of 1:2000 in PBS. Plates were then incubated in the same way, washed 4 times and examined microscopically.

Virus antibody detection in serum. Virological and serological examination was performed as described by Graham et al. (2003) with minor modifications. For antibody detection, $20 \mu$ of $1: 10$ and 1:20 dilutions of serum and a $20 \mu \mathrm{l}$ virus suspension containing 100 TCID $_{50}$ of the original reference SAV isolate F93-125 (Subtype 1) in EMEM containing 2\% FCS were mixed in a 96 -well plate. After incubation for $2 \mathrm{~h}$ at $20^{\circ} \mathrm{C}$, $2.5 \times 10^{4}$ CHSE-214 cells in $100 \mu$ l EMEM containing $5 \%$ FCS were added to each well. For detection of virus in serum, parallel wells on the same plate were inoculated with $20 \mu \mathrm{l}$ of 1:10 and 1:20 serum dilutions without addition of the reference SAV isolate virus. Plates were incubated in $5 \% \mathrm{CO}_{2}$ at $15^{\circ} \mathrm{C}$ for $5 \mathrm{~d}$ and then tested for the presence of SAV by IFAT.

RNA extraction. Viral RNA from $50 \mu \mathrm{l}$ of serum from each fish was isolated using High Pure Viral RNA Kit (Roche) according to the manufacturer's recommendations.

Total RNA was extracted from Atlantic salmon heart tissue using the RNeasy 96 Kit (Qiagen). Prior to extraction, 10 to $15 \mathrm{mg}$ tissue from each sample was homogenised in $600 \mu$ lysis buffer. The homogenisation was completed in a Mixer Mill MM 301 (Retch) using $3 \mathrm{~mm}$ tungsten carbide beads (Qiagen). The lysate was cleared in a prefilter plate (Whatman) before isolating total RNA according to the manufacturer's recommendations. The final volume of eluated RNA was $100 \mu \mathrm{l}$. Both serum and heart RNA were kept at $-80^{\circ} \mathrm{C}$ until use. Heart tissue or serum from noninfected and infected fish were always included in the assay as negative and positive controls respectively.

Reverse transcription (RT) and real-time PCR. A $3.8 \mu$ volume of RNA was reverse transcribed into cDNA using TaqMan Reverse Transcription Reagents (Applied Biosystems). The RT reaction mix contained $2.5 \mu \mathrm{M}$ random hexamers, $1 \times$ TaqMan RT buffer, $5.5 \mathrm{mM} \mathrm{MgCl}_{2}, 500 \mu \mathrm{M}$ dNTP, $0.4 \mathrm{U}_{\mu l^{-1}}$ RNase

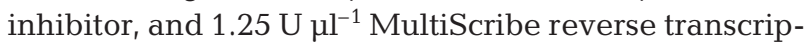
tase. The RT reaction was performed in a 96-well plate with a Gene Amp PCR System 2700 thermocycler (Applied Biosystems) by incubating at $25^{\circ} \mathrm{C}$ for $10 \mathrm{~min}$, followed by $30 \mathrm{~min}$ at $48^{\circ} \mathrm{C}$ and $5 \mathrm{~min}$ at $95^{\circ} \mathrm{C}$.

Aliquots of $5 \mu \mathrm{l}$ cDNA were then used for a duplex real-time PCR assay with TaqMan technology on an ABI prism 7000 real time PCR machine (Applied Biosystems) in 96-well plates. The detection of PDV cDNA was achieved using the following PCR primers located in PDV E1 and conserved among PDV isolates (sequences provided by K. Hodneland pers. comm.): UniversPD_E1-79F (5'-CCGCACGGTTGTAAGATCAGT-3') and UniversPD_E1-166R (5'-CGTC CGGAATGTTGATGGA-3'), both at a final concentration of 900 $\mathrm{nM}$ in the PCR reaction mixture, and the FAM-labelled TaqMan probe UniversPD_E1-106T (5'-CCGCTCCTGGCCCTCGATTGT-3') at a final concentration of $250 \mathrm{nM}$. A PCR primer/probe set for the detection of the cDNA of Atlantic salmon elongation factor $1 \alpha$ mRNA was also included in the assay as an internal control. These primers were EL.1A-ELAF (5'-CCCCTCCAGGACGTTTACAAA-3') and EL.1A-ELAR (5' CACACGGCCCACAGGTACA-3'), both at a final concentration of $40 \mathrm{nM}$, while the VIC-labelled TaqMan probe was EL.1A-ELAM1 (5'-ATCGGTGGTATTGGAAC-3') at a final concentration of $250 \mathrm{nM}$ (se- 
quences provided by I. Hordvik pers. comm.). In addition to the cDNA and the 2 primer/probe sets, the $25 \mu \mathrm{l}$ PCR reaction volume included $1 \times$ TaqMan Universal PCR Master Mix (Applied Biosystems) and PCR-grade water. The real-time PCR reaction was carried out with the following thermal profile: 1 step at $50^{\circ} \mathrm{C}$ for $2 \mathrm{~min}$ then 1 step at $95^{\circ} \mathrm{C}$ for $10 \mathrm{~min}$, followed by 45 amplification cycles each consisting of a denaturation phase at $95^{\circ} \mathrm{C}$ for $15 \mathrm{~s}$, and annealing/extension at $60^{\circ} \mathrm{C}$ for $1 \mathrm{~min}$. The real-time PCR reactions were set up and monitored using the ABI Prism 7000 SDS Software (Applied Biosystems). The fish was considered positive for the presence of PDV RNA when an exponential amplification curve was observed; otherwise, fish were determined to be negative. Results were interpreted in a semi-quantitative manner, with positive samples being assigned an ordinal score $(1+, 2+$ or $3+)$ based on the inverse relationship between the threshold cycle $\left(\mathrm{C}_{\mathrm{T}}\right)$ number and cDNA concentration.

\section{RESULTS}

\section{Symptoms and gross pathological changes}

No mortality or gross pathological changes were observed for any of the test groups during the experiment. At all sample points, the mean weight of the virus-inoculated group was lower than that of the control group, and the magnitude of this difference increased over the study period (Fig. 1). This difference was not significant at $7 \mathrm{~d}$ p.i. However, from then on, the weight of both challenge groups was significantly lower at each sample point $(14,21$ and $35 \mathrm{~d}$ p.i.: $\mathrm{p}<0.01 ; 70$ and $105 \mathrm{~d}$ p.i.: $\mathrm{p}<0.001$ ) with the exception of Group 1 at $21 \mathrm{~d}$ p.i.

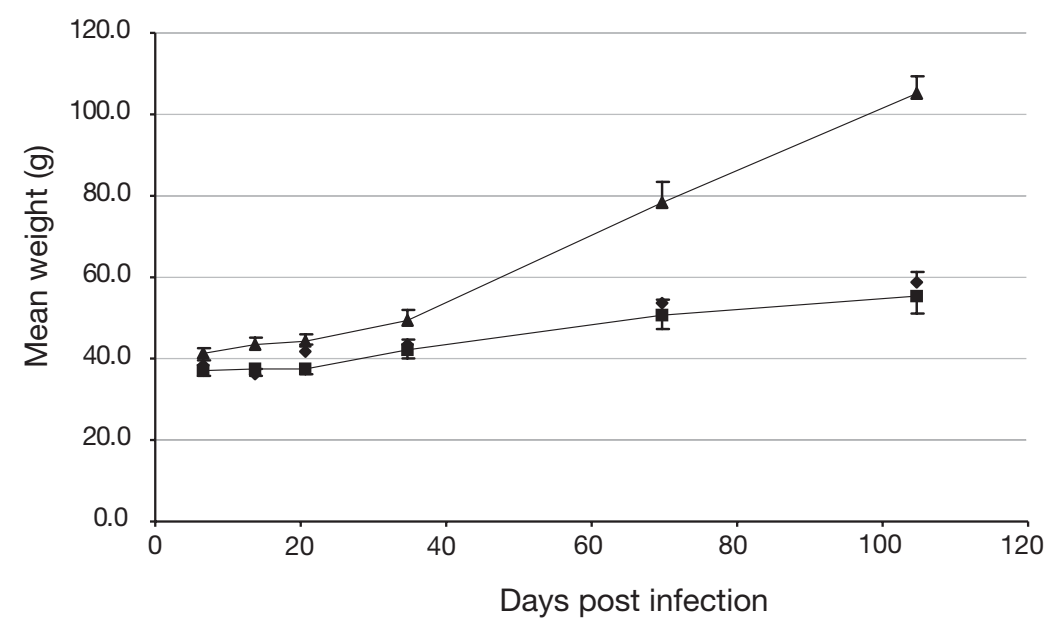

Fig. 1. Salmo salar. Mean weights $( \pm \mathrm{SE})$ of Group $1(\bullet)$, Group 2 (घ) and Group 3 ( $\mathbf{\Delta})$ fish at each sampling point

\section{Histopathology}

No lesions were observed in the control fish. The results of the histopathological examination of Groups 1 and 2 are summarized in Table 2 .

7 d p.i. In Group 1, early acute focal pancreatic acinar cell necrosis was detected in 1 fish along with degeneration in a few myocardial fibres. Mild focal periacinar tissue inflammation was also noted in 3 pancreatic sections. In a further 3 hearts there was evidence of very early mild focal cardiomyocytic degeneration. Mild focal epicarditis was observed in 4 fish. Findings were similar in Group 2, with early acute focal pancreatic acinar cell necrosis detected in 1 fish. Mild focal periacinar tissue inflammation was also noted for 3 pancreatic sections. In a further fish heart there was evidence of very early mild focal cardiomyocytic degeneration. No epicarditis was observed. No lesions were found in other organs examined from either group.

14 d p.i. All fish in Group 1 had developed varying degrees of pancreatic acinar cell necrosis and atrophy: 3 fish had focal pancreatic acinar necrosis, 4 had more widespread multifocal acinar cell necrosis with surviving cells and 3 had significant pancreatic atrophy with no detectable functioning acinar cells. Varying degrees of periacinar tissue and perivascular inflammation was also noted in the acutely affected sections. Mild focal to more severe diffuse multi-focal cardiomyocytic degeneration and necrosis was noted in all 10 fish. Lesions were noted in both the compact and spongy ventricular heart and occasionally in the atrium. Three fish had focal epicarditis and 1 had diffuse epicarditis. Five of the Group 2 fish exhibited a total absence of pancreatic acinar tissue, 4 had significant pancreatic atrophy with a few surviving acinar cells and 1 fish had relatively normal pancreatic appearance. Six fish had focal epicarditis and 1 had diffuse epicarditis. All had mild focal or moderate multifocal myocytic degeneration and necrosis similar to Group 1. No lesions were found in other organs examined.

21 d p.i. Nine Group 1 fish had varying degrees of pancreatic necrosis and atrophy: 1 had focal pancreatic acinar necrosis, 5 had more widespread multi-focal acinar cell necrosis with surviving cells and 3 had significant pancreatic atrophy with no detectable functioning acinar cells. Varying degrees of focal periacinar tissue and perivascular inflammation was also noted in affected sections. Mild to moderate multi-focal epicarditis was present in 5 fish and diffuse epicarditis 
Table 2. Salmo salar. Summary of histopathological findings. Ten fish were sampled from Groups 1 and 2 at each time point. The percentage of fish with lesions in each organ and severity of lesions were recorded, and mean lesion score calculated (mean score \pm SD given in parentheses). No lesions were observed in kidneys of these fish. No lesions were detected in control fish (Group 3); d p.i.: days post infection; nd: not done

\begin{tabular}{|c|c|c|c|c|c|c|}
\hline Group & d p.i. & $\begin{array}{c}\text { Pancreas } \\
\text { (acinar cells) }\end{array}$ & $\begin{array}{c}\text { Heart } \\
\text { (myocardium) }\end{array}$ & Red muscle & White muscle & Brain \\
\hline 1 & 7 & $10(0.1 \pm 0.3)$ & $40(0.4 \pm 0.5)$ & $0(-)$ & $0(-)$ & $0(-)$ \\
\hline 2 & 7 & $10(0.1 \pm 0.3)$ & $10(0.1 \pm 0.3)$ & $0(-)$ & $0(-)$ & $0(-)$ \\
\hline 1 & 14 & $100(2.0 \pm 0.8)$ & $100(1.5 \pm 0.7)$ & $0(-)$ & $0(-)$ & $0(-)$ \\
\hline 2 & 14 & $90(2.3 \pm 0.9)$ & $100(1.3 \pm 0.5)$ & $0(-)$ & $0(-)$ & $0(-)$ \\
\hline 1 & 21 & $90(2.0 \pm 0.9)$ & $90(1.3 \pm 0.7)$ & $10(0.1 \pm 0.3)$ & $10(0.1 \pm 0.3)$ & $0(-)$ \\
\hline 2 & 21 & $100(2.4 \pm 0.5)$ & $100(1.8 \pm 0.9)$ & $0(-)$ & $0(-)$ & $0(-)$ \\
\hline 1 & 35 & $60(1.2 \pm 1.1)$ & $60(0.6 \pm 0.5)$ & $0(-)$ & $60(0.6 \pm 0.5)$ & $0(-)$ \\
\hline 2 & 35 & $80(1.8 \pm 1.1)$ & $70(0.7 \pm 0.5)$ & $20(0.2 \pm 0.4)$ & $40(0.4 \pm 0.5)$ & $40(0.4 \pm 0.5)$ \\
\hline 1 & 70 & $10(0.3 \pm 0.9)$ & $10(0.1 \pm 0.3)$ & $0(-)$ & $10(0.1 \pm 0.3)$ & $0(-)$ \\
\hline 2 & 70 & $40(1.1 \pm 1.4)$ & $10(0.1 \pm 0.3)$ & $20(0.2 \pm 0.4)$ & $20(0.3 \pm 0.5)$ & $20(0.2 \pm 0.4)$ \\
\hline 1 & 105 & $10(0.2 \pm 0.6)$ & $20(0.2 \pm 0.4)$ & $0(-)$ & $0(-)$ & $0(-)$ \\
\hline 2 & 105 & $30(0.8 \pm 1.3)$ & $0(-)$ & $20(0.2 \pm 0.4)$ & $10(0.1 \pm 0.3)$ & $0(-)$ \\
\hline 1 & 140 & $20(0.5 \pm 1.1)$ & nd & $0(-)$ & $10(0.1 \pm 0.3)$ & $0(-)$ \\
\hline 2 & 140 & $20(0.5 \pm 1.1)$ & nd & $0(-)$ & $0(-)$ & $0(-)$ \\
\hline
\end{tabular}

in 2 fish. Mild focal to more severe diffuse multi-focal myocytic degeneration and necrosis was noted in 9 fish. Lesions were noted in both the compact and spongy ventricular heart and occasionally in the atrium. Mild focal myofibrillar degeneration was noted in the red and white muscle of 1 fish only. No lesions were found in heart, pancreas or muscle in 1 fish. Furthermore, no lesions were found in kidney or brains of any fish.

Four Group 2 fish exhibited a total absence of pancreatic acinar tissue and 6 exhibited significant pancreatic atrophy with a few surviving acinar cells. Five fish had mild focal epicarditis and 4 had diffuse epicarditis. All fish had mild focal to severe multifocal cardiomyocytic degeneration and necrosis. Lesions were noted in both the compact and spongy ventricular heart and occasionally in the atrium. No lesions were found in other organs examined.

35 d p.i. In Group 1, evidence of pancreatic recovery was present, with 4 fish having normal pancreatic acinar cell appearance. Four fish had significant atrophy but with some clumps of active acinar tissue, 1 had mild pancreatic atrophy and 1 exhibited a total absence of acinar tissue. Mild to moderate multi-focal epicarditis was present in 3 fish. Mild focal endocardial proliferation was observed in 4 fish, and hypertrophic nuclei indicating repair was observed in a further 2 fish. Overall heart lesions were very mild and not clinically significant. Mild focal myofibrillar degeneration was noted in the white muscle of 6 fish. No red muscle lesions were detected. In 1 fish, no lesions were found in the heart, pancreas or muscle. No lesions were found in kidney or brains.
In Group 2, 3 fish exhibited a total absence of pancreatic acinar tissue, 5 exhibited significant pancreatic atrophy with a few surviving acinar cells and 2 appeared relatively normal. Six fish had mild to moderate diffuse epicarditis and 3 had mild to moderate multifocal epicarditis. Three had no obvious lesions in the ventricle or atrium. The remainder had mild focal endocardial proliferation or mild inflammatory foci or hypertrophic nuclei, especially at the junction of the compact and spongy layers. Mild focal myofibrillar degeneration was noted in the red and white muscle of 1 fish. One fish had mild focal myofibrillar degeneration in red muscle only, and 3 fish had mild focal myofibrillar degeneration in white muscle only. Mild focal gliosis was present in the brains of 4 fish. No other lesions were detected.

70 d p.i. Only 1 fish exhibited continuing significant atrophy of pancreatic acinar tissue in Group 1. The remaining fish all exhibited apparently normal pancreatic architecture. This fish also had mild focal myofibrillar degeneration in white muscle only. Another fish had mild focal epicarditis and endocarditis. No lesions were found in kidney or brains. Three fish in Group 2 exhibited continuing significant atrophy of pancreatic acinar tissue, while 1 fish exhibited significant pancreatic atrophy but with some active pancreatic acinar cells. The remaining fish all exhibited apparently normal pancreatic architecture. One fish had mild focal endocardial proliferation, 1 had diffuse epicarditis and 1 fish had focal epicarditis, with the remaining hearts apparently normal. Mild focal myofibrillar degeneration was 
observed in both red and white muscle in 2 fish, with another fish having similar lesions in the white muscle only. Two fish had mild focal gliosis. No kidney lesions were found.

105 d p.i. One fish in Group 1 had significant pancreatic atrophy but with some active pancreatic acinar cells. The remaining fish all had apparently normal pancreatic architecture. Two fish had mild focal endocardial proliferation. No lesions were detected in the muscle, kidney or brain. In Group 2, 2 fish exhibited continuing significant atrophy of pancreatic acinar tissue, while 1 fish exhibited significant pancreatic atrophy but with some active pancreatic acinar cells. One of these fish also had mild focal myofibrillar degeneration in both red and white muscle, while another had similar lesions in the red muscle only. No lesions were detected in the kidney or brain.

140 d p.i. No heart samples were collected at this point. In Group 1, 1 fish still exhibited continuing significant atrophy of pancreatic acinar tissue and 1 exhibited significant pancreatic atrophy but with some active pancreatic acinar cells. Mild focal myofibrillar degeneration was detected in the white muscle of this latter fish only. No other lesions were detected. Similar pancreatic lesions were found in 2 fish in Group 2. No other lesions were detected.

Statistical analyses. Comparisons of the proportions of fish with and without lesions in each organ at each sample point were compared by equality of proportions using Fisher's exact test to allow for small sample size. No significant differences were found at the $5 \%$ level; however, the higher proportion of brain lesions observed at $35 \mathrm{~d}$ p.i. in Group 2 was significant at the $10 \%$ level ( $p=0.087)$. Brain lesions were also observed in this group at $70 \mathrm{~d}$ p.i. No brain lesions were observed in Group 1 at any sampling event. Overall, the difference between the 2 groups in terms of the frequency with which brain lesions were observed was not significant ( $p=0.27$, Fisher's exact test)

To examine the differences in the severity of the lesions for each organ type at each time point, the median lesion scores of the 2 groups were compared using the non-parametric Kruskal-Wallis test. No significant differences were detected.

\section{Virus isolation}

SAV was isolated from 5 of 10,9 of 10 and 8 of 9 sera from Group 1 at 4, 7 and $14 \mathrm{~d}$ p.i. respectively (Table 3). Serum was only collected from Group 2 from $14 \mathrm{~d}$ p.i. onwards. At $14 \mathrm{~d}$ p.i., 6 of 10 Group 2 fish were viraemic. SAV was not isolated from either group at subsequent time points. No significant differences in the proportions of virus-positive sera were detected at any time point between Groups 1 and 2 (Fisher's exact test).

SAV was isolated from kidney tissue from 8 of 9 fish from Group 1 at 7 d p.i. and from 9 of 9 fish at 14 d p.i. (Table 2). For Group 2, SAV was isolated from kidney tissue from 4 of 4 fish at $7 \mathrm{~d}$ p.i. and 5 of 5 fish at $14 \mathrm{~d}$ p.i. respectively. Results were not available for a minority of samples taken owing to a number of factors that included bacterial overgrowth and available sample size.

Overall, there was good correlation between results from serum and kidney; however, on 3 occasions (1 fish from Group 1 and 2 from Group 2), virus was isolated from kidney tissue but not from serum (Table 3). SAV was not isolated from serum or kidney samples from the control fish (Group 3).

\section{SAV serology}

Neutralizing antibodies were first detected in both Groups 1 and 2 at $21 \mathrm{~d}$ p.i., when 7 of 10 and 4 of 10 sera respectively had titres of $\geq 1 / 20$ (Table 4 ). Thereafter, seroprevalence increased, remaining between 80 and $100 \%$ in both groups. The geometric mean titre (GMT) in both groups peaked at $70 \mathrm{~d}$ p.i., with values

Table 3. Salmo salar. Results of virus isolation from serum for sets of fish from Groups 1 and 2 sampled at different time points. Virus isolation was performed on kidney tissue taken from these same fish at 7 and $14 \mathrm{~d}$ p.i. (results for 7 and $14 \mathrm{~d}$ p.i. presented as serum/kidney); ns: not sampled; na: not available

\begin{tabular}{|c|c|c|c|c|c|c|}
\hline & 4 & 7 & $\begin{array}{c}\text { Days p.i. } \\
14\end{array}$ & 21 & 35 & 70 \\
\hline \multicolumn{7}{|c|}{ Group 1} \\
\hline 1 & - & $+/+$ & $+/+$ & - & - & - \\
\hline 2 & + & $+/+$ & $+/+$ & - & - & - \\
\hline 3 & + & $+/+$ & $+/+$ & - & - & - \\
\hline 4 & + & $+/+$ & $+/+$ & - & - & - \\
\hline 5 & - & $-1-$ & $-1+$ & - & - & - \\
\hline 6 & + & $+/+$ & $+/$ na & - & - & - \\
\hline 7 & - & $+/+$ & $+/+$ & - & - & - \\
\hline 8 & + & $+/+$ & $+/+$ & - & - & - \\
\hline 9 & - & $+/+$ & $+/+$ & - & - & - \\
\hline 10 & - & $+/$ na & na/+ & - & - & - \\
\hline \multicolumn{7}{|c|}{ Group 2} \\
\hline 1 & ns & $+/ \mathrm{ns}$ & $+/+$ & - & - & - \\
\hline 2 & ns & $+/ \mathrm{ns}$ & t/t & - & - & - \\
\hline 3 & ns & $+/ \mathrm{ns}$ & $-1+$ & - & - & - \\
\hline 4 & ns & ns/na & $+/+$ & - & - & - \\
\hline 5 & ns & $+/ \mathrm{ns}$ & $-1+$ & - & - & - \\
\hline 6 & ns & $\mathrm{ns} / \mathrm{ns}$ & $+/ \mathrm{ns}$ & - & - & - \\
\hline 7 & ns & $\mathrm{ns} / \mathrm{ns}$ & $-/ \mathrm{ns}$ & - & - & - \\
\hline 8 & ns & $\mathrm{ns} / \mathrm{ns}$ & $-/ \mathrm{ns}$ & - & - & - \\
\hline 9 & ns & $\mathrm{ns} / \mathrm{ns}$ & $+/ \mathrm{ns}$ & - & - & - \\
\hline 10 & ns & $\mathrm{ns} / \mathrm{ns}$ & $+/ \mathrm{ns}$ & - & - & - \\
\hline
\end{tabular}


of 5.72 and 5.10 respectively. No antibodies were detected in the control group at any sampling point. No significant differences in the proportions of antibodypositive sera were detected at any time point between Groups 1 and 2 (Fisher's exact test). However, the GMT of positive Group 1 samples at 35 d p.i. was found to be significantly higher than that of positive Group 2 samples (5.66 vs. 4.92, $\mathrm{p}=0.044$ ).

\section{Detection of SAV RNA in heart and serum by real-time RT-PCR}

Detection of SAV RNA in heart tissue by real-time RT-PCR was examined for Groups 1 and 3 only, with the exception of 30 Group 2 fish sampled at $140 \mathrm{~d}$ p.i. At 7, 14 and $21 \mathrm{~d}$ p.i., SAV-specific RNA was detected in 10 of 10, 9 of 10 and 10 of 10 Group 1 fish (Table 5). At 35 d p.i., 8 of 10 fish were positive, and at 70, 105 and $140 \mathrm{~d}$ p.i., 1 of 10,2 of 10 and 1 of 10 fish were positive. Based on the $\mathrm{C}_{\mathrm{T}}$ values of the positive samples, levels of viral RNA in heart were high until $21 \mathrm{~d}$ p.i., declining to low levels thereafter. Six of 30 hearts from

Table 4. Salmo salar. Results of serological testing for Groups 1 and 2. Sera were tested individually and their reciprocal end-point titre determined. The geometric mean titre (GMT) \pm SD of positive sera for each group at each time point was calculated; ns: not sampled; -: $<20$ (negative)

\begin{tabular}{|lcccccccc|}
\hline \multicolumn{7}{c}{ Days p.i. } \\
& & & \multicolumn{7}{c}{} & & & \\
& 4 & 7 & 14 & 21 & 35 & 70 & 105 & 140 \\
\hline Group 1 & & & & & & & & \\
1 & - & - & - & 20 & 40 & 80 & 40 & 20 \\
2 & - & - & - & - & 80 & 80 & - & 40 \\
3 & - & - & - & 20 & 40 & 80 & 80 & 20 \\
4 & - & - & - & 40 & 20 & 40 & 20 & 40 \\
5 & - & - & - & - & 80 & 160 & 40 & 20 \\
6 & - & - & - & 20 & 80 & 20 & 20 & 40 \\
7 & - & - & - & 20 & 40 & 20 & - & 40 \\
8 & - & - & - & 20 & 40 & 40 & 40 & 40 \\
9 & - & - & - & 40 & 80 & 20 & 40 & - \\
10 & - & - & - & - & - & 160 & 80 & 20 \\
GMT & & & & 4.61 & 5.66 & 5.72 & 5.1 & 4.88 \\
\pm SD & & & & \pm 0.49 & \pm 0.71 & \pm 1.17 & \pm 0.97 & \pm 0.53 \\
Group 2 & & & & & & & & \\
1 & ns & ns & - & - & 40 & 40 & 40 & 80 \\
2 & ns & ns & - & - & 40 & 20 & 40 & 20 \\
3 & ns & ns & - & 20 & 40 & 40 & 80 & - \\
4 & ns & ns & - & 20 & 40 & 40 & 20 & 40 \\
5 & ns & ns & - & - & 40 & 80 & - & - \\
6 & ns & ns & - & - & 40 & 40 & 20 & 20 \\
7 & ns & ns & - & 20 & 20 & 20 & 20 & 20 \\
8 & ns & ns & - & - & 20 & - & 40 & 20 \\
9 & ns & ns & - & - & 20 & 20 & - & 20 \\
10 & ns & ns & - & 20 & 20 & 40 & 20 & 40 \\
GMT & & & & 4.3 & 4.92 & 5.10 & 4.77 & 4.82 \\
\pm SD & & & & \pm 0.0 & \pm 0.52 & \pm 0.69 & \pm 0.88 & \pm 0.76 \\
& & & & & & & & \\
\hline
\end{tabular}

Group 2 fish sampled at 140 d p.i. were positive at a low level.

When sera were tested, 9 of 10 and 10 of 10 Group 1 fish were positive at 4 and $7 \mathrm{~d}$ p.i. (Table 5). Samples were not collected from Group 2 at these points; however, at $14 \mathrm{~d}$ p.i., 5 of 10 and 6 of 10 fish in Groups 1 and 2 were positive, with very significantly higher levels of RNA detected in Group 2 (Mann-Whitney test, p < 0.01). In contrast to the results from heart samples, no Group 1 sera were positive by PCR from $21 \mathrm{~d}$ p.i. onwards; however, 2 of 10 and 1 of 10 Group 2 fish were positive at 35 and $70 \mathrm{~d}$ p.i. respectively. No RNA was detected in heart or serum from the control group at any time. No significant differences in the proportions of PCR-positive sera were detected at any time point between Groups 1 and 2 (Fisher's exact test).

\section{DISCUSSION}

This is the first comparative experimental study of SAV Subtypes 1 and 3 in Atlantic salmon. Overall, the absence of mortalities and the histopathological changes observed were similar to, and consistent with, reports of similar studies (Boucher et al. 1995, Boucher \& Baudin Laurencin 1996, McLoughlin et al. 1996, Desvignes et al. 2002, Weston et al. 2002).

The sequential pathological changes followed similar patterns in Groups 1 and 2, albeit with some (nonsignificant) variations in both the prevalence and severity of lesions in some tissues at some time points. Epicarditis was prevalent in both groups from 14 to 35 d p.i., being more severe in Group 2. Epicarditis has not been documented before in experimental SAV infections and shows some similarities to the pathological changes associated with heart and skeletal muscle inflammation (HSMI; Kongtorp et al. 2004, Ferguson et al. 2005). The muscle lesions observed were very mild and much less severe than those seen in experimental SD in rainbow trout (Boucher \& Baudin Laurencin 1996). Focal gliosis in the brainstem was the last lesion to develop, appearing first at $35 \mathrm{~d}$ p.i. in Group 2 only, and also being present at $70 \mathrm{~d}$ p.i. Similar lesions have also been observed in farmed Atlantic salmon undergoing a sub-clinical infection with SAV (M. McLoughlin pers. obs.). The significance and aetiology of these lesions remains to be determined, but a viral cause is hypothesized based on the known neuro-tropism of other alphaviruses (Levine \& Griffin 1992, Amor et al. 1996) and the absence of lesions in control fish. This is supported by the detection of specific staining by immunohistochemistry in the brain of rainbow trout experimentally infected with Subtype 2 SAV (Kerbart Boscher et al. 2003). 
Table 5. Salmo salar. Individual and total results of SAV real-time RT-PCR testing on heart and serum for fish from Groups 1 and 2 at each time point (results given as heart/serum). Real-time RT-PCR was interpreted in a semi-quantitative manner and the amount of RNA present in positive samples expressed on an ordinal scale from $1+$ to $3+$; ns: not sampled; - : not detected; No. pos.: number positive

\begin{tabular}{|c|c|c|c|c|c|c|c|c|}
\hline \multirow[t]{2}{*}{ Fish } & \multicolumn{7}{|c|}{ Days p.i. } & \multirow[b]{2}{*}{140} \\
\hline & 4 & 7 & 14 & 21 & 35 & 70 & 105 & \\
\hline \multicolumn{9}{|l|}{ Group 1} \\
\hline A & $\mathrm{ns} / 1+$ & $3+/ 1+$ & $3+/ 1+$ & $3+/-$ & $-/-$ & $-1-$ & $1+/-$ & $-/ \mathrm{ns}$ \\
\hline B & ns/1+ & $3+/ 2+$ & $-/ 1+$ & $3+/-$ & $1+/-$ & $-1-$ & $-/-$ & $-/ \mathrm{ns}$ \\
\hline $\mathrm{C}$ & $\mathrm{ns} / 2+$ & $3+/ 2+$ & $3+/ 1+$ & $3+/-$ & $2+/-$ & $-1-$ & $1+/-$ & $-/ \mathrm{ns}$ \\
\hline D & ns/1+ & $2+/ 2+$ & $3+/-$ & $3+/-$ & $2+/-$ & $-1-$ & $-/-$ & $-/ \mathrm{ns}$ \\
\hline E & ns/- & $2+/ 3+$ & $3+/ 1+$ & $3+/-$ & $2+/-$ & $-1-$ & $-1-$ & $-/ \mathrm{ns}$ \\
\hline $\mathrm{F}$ & ns $/ 2+$ & $3+/ 3+$ & $3+/ 1+$ & $3+1-$ & $-1-$ & $-1-$ & $-1-$ & $-/ \mathrm{ns}$ \\
\hline G & $\mathrm{ns} / 1+$ & $2+/ 1+$ & $3+/-$ & $2+/-$ & $2+/-$ & $-/-$ & $-/-$ & $1+/ \mathrm{ns}$ \\
\hline $\mathrm{H}$ & ns/2+ & $3+/ 3+$ & $2+/-$ & $2+/-$ & $1+/-$ & $1+/-$ & $-1-$ & $-/ \mathrm{ns}$ \\
\hline I & ns/2+ & $2+/ 1+$ & $3+/-$ & $3+1-$ & $2+/-$ & $-1-$ & $-1-$ & $-/ \mathrm{ns}$ \\
\hline $\mathrm{J}$ & $\mathrm{ns} / 2+$ & $3+/ 3+$ & $3+/-$ & $3+/-$ & $1+/-$ & $-1-$ & $-/-$ & $-/ \mathrm{ns}$ \\
\hline No. pos. & $\mathrm{ns} / 9$ & $10 / 10$ & $9 / 5$ & $10 / 0$ & $8 / 0$ & $1 / 0$ & $2 / 0$ & $1 / 0$ \\
\hline \multicolumn{9}{|l|}{ Group 2} \\
\hline A & $\mathrm{ns} / \mathrm{ns}$ & $\mathrm{ns} / \mathrm{ns}$ & $\mathrm{ns} / 3+$ & $\mathrm{ns} /-$ & ns/- & ns/- & ns/- & $\mathrm{a} / \mathrm{ns}$ \\
\hline B & $\mathrm{ns} / \mathrm{ns}$ & $\mathrm{ns} / \mathrm{ns}$ & $\mathrm{ns} / 3+$ & ns/- & ns/- & ns/- & ns/- & $\mathrm{a} / \mathrm{ns}$ \\
\hline $\mathrm{C}$ & $\mathrm{ns} / \mathrm{ns}$ & ns/ns & ns/- & ns/- & ns/- & $\mathrm{ns} /-$ & $\mathrm{ns} /-$ & $\mathrm{a} / \mathrm{ns}$ \\
\hline D & $\mathrm{ns} / \mathrm{ns}$ & ns/ns & $\mathrm{ns} / 3+$ & $\mathrm{ns} /-$ & ns/- & ns/- & ns/- & $\mathrm{a} / \mathrm{ns}$ \\
\hline E & $\mathrm{ns} / \mathrm{ns}$ & $\mathrm{ns} / \mathrm{ns}$ & ns/- & ns/- & ns/- & $\mathrm{ns} / 2+$ & $\mathrm{ns} / 1+$ & $\mathrm{a} / \mathrm{ns}$ \\
\hline $\mathrm{F}$ & $\mathrm{ns} / \mathrm{ns}$ & $\mathrm{ns} / \mathrm{ns}$ & $\mathrm{ns} / 3+$ & ns/- & $\mathrm{ns} /-$ & $\mathrm{ns} / 1+$ & ns/- & $\mathrm{a} / \mathrm{ns}$ \\
\hline $\mathrm{G}$ & $\mathrm{ns} / \mathrm{ns}$ & ns/ns & ns/- & ns/- & ns/- & ns/- & ns/- & $\mathrm{a} / \mathrm{ns}$ \\
\hline $\mathrm{H}$ & $\mathrm{ns} / \mathrm{ns}$ & $\mathrm{ns} / \mathrm{ns}$ & ns/- & ns/- & ns/- & ns/- & ns/- & $\mathrm{a} / \mathrm{ns}$ \\
\hline I & $\mathrm{ns} / \mathrm{ns}$ & $\mathrm{ns} / \mathrm{ns}$ & $\mathrm{ns} / 3+$ & ns/- & ns/- & ns/- & ns/- & $\mathrm{a} / \mathrm{ns}$ \\
\hline J & $\mathrm{ns} / \mathrm{ns}$ & $\mathrm{ns} / \mathrm{ns}$ & $\mathrm{ns} / 3+$ & ns/- & ns/- & ns/- & $\mathrm{ns} /-$ & $\mathrm{a} / \mathrm{ns}$ \\
\hline No. pos. & $\mathrm{ns} / \mathrm{ns}$ & ns/ns & $\mathrm{ns} / 6$ & $\mathrm{~ns} / 0$ & $\mathrm{~ns} / 0$ & $\mathrm{~ns} / 2$ & $\mathrm{~ns} / 1$ & $\mathrm{a} / \mathrm{ns}$ \\
\hline
\end{tabular}

The current study (140 d) is much longer than previous experimental infections, which typically lasted 20 to 42 d (Boucher et al. 1995, Boucher \& Baudin Laurencin 1996, McLoughlin et al. 1996, Desvignes et al. 2002, Weston et al. 2002). This has allowed extended profiles for both Subtype 1 and 3 SAVs to be developed. It can be seen that while recovery was evident in the pancreas of both Group 1 (40\%) and Group $2(20 \%)$ by 35 d p.i., fish with significant chronic pancreatic atrophy were present in both groups (particularly Group 2) at this and all subsequent sampling points. None of these fish had significant inflammation of the periacinar tissue, indicating a failure of pancreatic recovery. This type of lesion has previously been associated with so-called postPD runts (McLoughlin et al. 2002). Consistent with this, both SAV subtypes resulted in significantly reduced weight gains compared with the controls, which exceeded $40 \%$ in both groups by $105 \mathrm{~d}$ p.i. This is the first time that this effect has been reported, and suggests that-in addition to mortali- ties-reduced growth may contribute markedly to the overall economic loss associated with outbreaks of PD or SD.

Renal changes characterized by numerous macrophage-like cells filled with eosinophilic material in the interstitium have been described in field infections of Subtype 3 SAV infections in Norway (T. Taksdal pers. comm.), but were not observed in the current trial.

Failure to isolate virus from the serum of some fish in which the kidney was positive may reflect differences in the viral loads of these samples, in the amount of each inoculated, or the incubation periods and cell culture passages for each sample type. Nevertheless, the ease with which serum samples can be screened for infectious SAV relative to tissue samples still makes them a suitable alternative option for screening populations of fish, particularly when conducting longitudinal surveys where serology is also being performed (Graham et al. 2007).

The virological and serological changes in Groups 1 and 2 were similar to those observed previously with SAV Subtype 1 experimental infections (McLoughlin et al. 1996, 2006). Thus, viraemia was still detectable at 14 d p.i., when all tested fish were negative for virus neutralizing (VN) antibodies. By 21 d p.i., viraemia was no longer detectable (Table 3) and VN antibodies were present in some fish in both groups (Table 4).

While the genotypic differences between Subtype 1 and Subtype 3 viruses are now well characterized (Hodneland et al. 2005, Weston et al. 2005), the antigenic and serological relationships between subtypes remain to be clearly defined. Our results demonstrate that the VN antibody responses of fish in both Groups 1 and 2 were broadly similar, with no significant differences in seroprevalence at any sample point. This suggests that the subtypes are not sufficiently distinct to represent different serotypes. However, the observation that the GMT of seropositive fish was consistently higher from $21 \mathrm{~d}$ p.i. onwards (albeit only significantly so at $35 \mathrm{~d}$ p.i.) in the Group 1 fish suggests that antigenic differences do exist. An understanding of the extent of such differences is particularly important in relation to vaccine development and usage, in order to ensure that protection against heterologous subtypes is sufficient. 
The results of the RT-PCR testing on sera show that 90 and $100 \%$ of samples from Group 1 were positive at 4 and 7 d p.i. respectively (Table 3 ), declining to $50 \%$ at $14 \mathrm{~d}$ p.i. The data also indicate that the level of viral RNA peaked at $7 \mathrm{~d}$ p.i. in this experiment. Because the sera taken for RT-PCR testing and virus isolation at each time point came from different fish, it is not possible to make a direct comparison of the results at the individual fish level; however, overall RT-PCR seemed to detect viraemic fish earlier than did virus isolation. In relation to diagnostic testing, the results demonstrated that heart samples are superior to serum samples for detecting previous SAV infection, particularly as it enters the chronic stage.

The epidemiological significance of the persistence of viral RNA in heart tissue remains to be determined. A number of hypotheses may be proposed. First, that these fish represent true carriers, capable of maintaining infection in a population and of transmitting virus to susceptible fish. However, it remains to be proven that live virus is recoverable from these fish. Second, that these fish are persistently infected, but epidemiologically insignificant because the virus is locked in by the host immune response. Third, that these findings merely represent low levels of RNA remaining from the original infection.

Levine \& Griffin (1992) demonstrated that clearance of Sindbis virus, the prototype alphavirus, from the central nervous system (CNS) of mice is mediated by antibody-induced restriction of viral gene expression rather than by T-cell activity. Thereafter, long-term persistence of viral RNA could occur in a non-productive form, with the humoral immune response (particularly to the E2 glycoprotein) playing an important role in preventing viral reactivation. Levine \& Griffin (1992) hypothesized that waning immunity or immunosuppression could lead to viral reactivation. With Semliki Forest virus, another alphavirus, persistence of viral RNA (but not infectious virus) in neurons of the mouse CNS in the presence of a humoral immune response has also been demonstrated (Amor et al. 1996). Resisen et al. (2004) failed to find evidence of a role for chronic avian infection as the mechanism for alphavirus-induced encephalitis persistent and dispersal.

Taken together, these results suggest that whilst alphaviral RNA can persist in vertebrate hosts, such infections are abortive in the presence of a humoral immune response. This suggests that the SAV-RNA detected in heart in the latter stages of the current study is epidemiologically insignificant and that these fish are not true carriers. However, other studies by La Linn et al. (1996) and Way et al. (2002) showed that Ross River virus, another alphavirus, can produce long-term persistent and productive infection in murine macrophage cell lines. It is evident that further experimental studies are needed to explore this aspect of the epidemiology of SAV infections.

In conclusion, this experiment did not identify significant differences in the pathological, serological or virological responses produced by experimental infection of Atlantic salmon with SAV Subtypes 1 and 3. However, both viruses produced a significant reduction in weight gain compared with control fish. RT-PCR was found to be more sensitive than cell culture for detection of virus in serum, and viral RNA was shown to persist in heart tissue in some fish for $\geq 140 \mathrm{~d}$ p.i. The epidemiological significance of this finding needs to be clarified. The results demonstrate the suitability of virus isolation, RT-PCR and serology in the diagnosis of SAV infections.

Acknowledgements. The assistance of Irene Gabestad with the real-time PCR is gratefully acknowledged.

\section{LITERATURE CITED}

Amor SA, Scallan MF, Morris MM, Dyson H, Fazakerley JK (1996) Role of immune responses in protection and pathogenesis during Semliki Forest virus encephalitis. J Gen Virol 77:281-291

Boucher P, Baudin Laurencin F (1996) Sleeping disease and pancreas disease: comparative histopathology and acquired cross-protection. J Fish Dis 19:303-310

Boucher P, Raynard RS, Houghton G, Baudin Laurencin F (1995) Comparative experimental transmission of pancreas disease in Atlantic salmon, rainbow trout and brown trout. Dis Aquat Org 22:19-24

Desvignes L, Quentel C, Lamour F, Le Ven A (2002) Pathogenesis and immune response in Atlantic salmon (Salmo salar L.) parr experimentally infected with salmon pancreas disease virus (SPDV). Fish Shellfish Immunol 12: 77-95

Ferguson HW, Kongtorp RT, Taksdal T, Graham DA, Falk K (2005) An outbreak of disease resembling heart and skeletal muscle inflammation (HSMI) in Scottish farmed salmon (Salmo salar L.) with observations on myocardial degeneration. J Fish Dis 28:119-123

Graham DA, Jewhurst VA, Rowley HM, McLoughlin MF, Todd D (2003) A rapid immunoperoxidase-based virus neutralization assay for salmonid alphavirus. J Fish Dis 26: 407-413

Graham DA, Jewhurst HL, McLoughlin MF, Branson EJ, McKenzie K, Rowley HM, Todd D (2007) Serological, virological and histopathological study of an outbreak of sleeping disease in farmed rainbow trout Oncorhynchus mykiss. Dis Aquat Org 74:191-197

Hodneland K, Bratland A, Christie KE, Endresen, Nylund A (2005) New subtype of salmonid alphavirus (SAV), Togaviridae, from Atlantic salmon Salmo salar and rainbow trout Oncorynchus mykiss in Norway. Dis Aquat Org 66:113-120

Jewhurst VA, Todd D, Rowley HM, Walker IW, Weston JH, McLoughlin MF, Graham DA (2004) Detection and antigenic characterization of salmonid alpha virus isolates from sera obtained from farmed Atlantic salmon, Salmo 
salar L., and farmed rainbow trout, Oncorhynchus mykiss (Walbaum). J Fish Dis 27:143-149

Kerbart Boscher S, McLoughlin M, Le Ven A, Cabon J, Baud M, Castric J (2003) Experimental transmission of sleeping disease in one-year-old rainbow trout, Oncorhyncus mykiss (Walbaum), induced by sleeping disease virus. J Fish Dis 29:263-273

Kongtorp RT, Taksdal T, Lyngøy A (2004) Pathology of heart and skeletal muscle inflammation (HSMI) in farmed Atlantic salmon Salmo salar. Dis Aquat Org 59: $217-224$

La Linn M, Aaskov JG, Suhrbier A (1996) Antibody-dependent enhancement and persistence in macrophages of an arbovirus associated with arthritis. J Gen Virol 77: 407-411

Levine BL, Griffin DE (1992) Persistence of viral RNA in mouse brains after recovery from acute alphavirus encephalitis. J Virol 66:6429-6435

McLoughlin MF, Nelson RT, Rowley HM, Cox DI, Grant AN (1996) Experimental pancreas disease in Atlantic salmon Salmo salar post-smolts induced by salmon pancreas disease virus (SPDV). Dis Aquat Org 26:117-124

McLoughlin MF, Nelson RT, McCormick JI, Rowley HM, Bryson DB (2002) Clinical and histopathological features

Editorial responsibility: Jo-Ann Leong,

Kaneohe, Hawaii, USA of naturally occurring pancreas disease in farmed Atlantic salmon Salmo salar L. J Fish Dis 25:33-43

McLoughlin MF, Graham DA, Norris A, Matthews D and 5 others (2006) Virological, serological and histopathological evaluation of fish strain susceptibility to experimental infection with salmonid alphavirus. Dis Aquat Org 72:125-133

Reisen WK, Chiles RE, Martinez VM, Fang Y, Green EN (2004) Encephalitis virus persistence in California birds: experimental infections in mourning doves (Zenaidura macroura). J Med Entomol 41:462-466

Way SJR, Lidbury BA, Banyer JL (2002) Persistent Ross River virus infection on murine macrophages: an in vitro model of the study of viral relapse and immune modulation during long-term infection. Virology 301:281-292

Welsh M, Weston J, Borghmans BJ, Mackie D, Rowley H, Nelson R, McLoughlin MF, Todd D (2000) Biochemical characterization of salmon pancreas disease virus. J Gen Virol 81:813-820

Weston J, Villoing S, Brémont M, Castric J and 7 others (2002) Comparison of two aquatic alphaviruses, salmon pancreas disease virus and sleeping disease virus, by using genome sequence analysis, monoclonal reactivity, and cross-infection. J Virol 76:6155-6163

Submitted: May 2, 2006; Accepted: January 24, 2007

Proofs received from author(s): March 21, 2007 